\title{
The effect of two phosphodiesterase inhibitors on bone healing in mandibular fractures (animal study in rats)
}

\author{
Mohsen MalekiGorji ${ }^{1}$, Arash Golestaneh ${ }^{1}$, Seyyed Mohammad Razavi² \\ ${ }^{1}$ Department of Oral and Maxillofacial Surgery, Dental School, Islamic Azad University, Isfahan (Khorasgan) Branch, \\ ${ }^{2}$ Torabinejad Dental Research Center and Department of Oral and Maxillofacial Pathology, School of Dentistry, \\ Isfahan University of Medical Sciences, Isfahan, Iran
}

\begin{abstract}
J Korean Assoc Oral Maxillofac Surg 2020;46:258-265)
Objectives: Despite advances in maxillofacial surgery, impaired bone healing remains a concern for surgical teams. Many studies have evaluated the effects of sildenafil and pentoxifylline on bone healing. However, their effects on healing of bone fractures have not been well investigated. This study aimed to assess the effects of the phosphodiesterase inhibitors sildenafil and pentoxifylline on healing of mandibular fractures in rats.

Materials and Methods: A total of 60 rats were randomly divided into six groups of 10. Mandibular fracture was induced in all rats. After the surgical procedure, group C1 received saline, group S1 received $10 \mathrm{mg} / \mathrm{kg}$ sildenafil and group P1 received $50 \mathrm{mg} / \mathrm{kg}$ pentoxifylline. The rats were sacrificed after 1 week. Groups C4, S4, and P4 received pharmaceutical therapy as in groups C1, S1, and P1 but were sacrificed after 4 weeks. The samples then underwent histological analysis.

Results: The mean rate of bone healing of mandibular fractures in groups S1 and P1 was significantly higher than in group $\mathrm{C} 1$ at 1 week $(P<0.001)$. The mean rate of bone healing of mandibular fractures in group P1 was higher than in group S1 at 1 week $(P=0.04)$. The mean rate of bone healing of mandibular fractures in groups S4 $(P=0.001)$ and $\mathrm{P} 4(P=0.004)$ was significantly higher than in group $\mathrm{C} 4$ at 4 weeks, but no significant difference was noted in the rate of healing between groups $\mathrm{P} 4$ and $\mathrm{S} 4(P=0.53)$.
\end{abstract}

Conclusion: Sildenafil and pentoxifylline can be used as adjuncts to enhance bone healing in rats.

Key words: Bone regeneration, Mandibular fracture, Pentoxifylline, Sildenafil

[paper submitted 2019. 9. 22 / revised 2019. 12. 9 / accepted 2019. 12. 17]

\section{Introduction}

Successful management of maxillofacial fractures depends on correct reduction and precise fixation of broken segments in order to achieve a normal occlusion, resume function, and properly align the broken pieces next to each other ${ }^{1}$. Despite advances in maxillofacial surgery, impaired bone healing remains a concern for surgical teams ${ }^{2}$. Mandibular fractures are among the most common of the maxillofacial region, ac-

\footnotetext{
Arash Golestaneh

Department of Oral and Maxillofacial Surgery, Dental School, Islamic Azad University, Isfahan (Khorasgan) Branch, University Blv, Arghavanieh St, East Jey St, Isfahan 8155139998, Iran

TEL: +98-9131116547 FAX: +98-3131313330

E-mail:drgolestaneh@gmail.com

ORCID: https://orcid.org/0000-0003-4455-7049

(c) This is an open-access article distributed under the terms of the Creative Commons Attribution Non-Commercial License (http://creativecommons.org/ licenses/by-nc/4.0/), which permits unrestricted non-commercial use, distribution, and reproduction in any medium, provided the original work is properly cited.

Copyright (C) 2020 The Korean Association of Oral and Maxillofacial Surgeons. All rights reserved.
}

counting for $23 \%$ to $97 \%$ of all facial fractures ${ }^{3,4}$.

Bone healing is a complex process that includes three stages: inflammation, repair, and delayed remodeling. This biological process is controlled by complex cellular and molecular mechanisms. Systemic and local factors, as well as several cell types and growth factors delivered via the adjacent tissues and blood stream, all play a role in bone healing ${ }^{5-7}$. A number of studies have evaluated growth factors, injection of medications and electrical stimulation to accelerate and enhance bone healing ${ }^{8-10}$. Other studies have indicated that some medications, such as antibiotics and bisphosphonates, delay or impair the process of bone healing. By having a comprehensive understanding of these factors and not prescribing these medications in cases of fracture, complete bone healing can be expected ${ }^{11,12}$. Bleeding at the site of injury is the most important factor for successful bone healing ${ }^{13}$. Decreased angiogenesis at the site of trauma and limited blood supply to the site are known to delay or impair the process of bone healing ${ }^{14,15}$. Nitric oxide and vasodilation 
are imperative for angiogenesis, and the positive effects of nitric oxide on wound healing are probably due its functional effects on angiogenesis and inflammation ${ }^{16-18}$.

Sildenafil, a selective phosphodiesterase-5 inhibitor, prevents the degradation of nitric oxide and is a potent stimulator of angiogenesis. Phosphodiesterase-5 results in degradation of cyclic guanosine monophosphate, which relaxes smooth muscle $^{19}$. Sildenafil is a vasodilator of the peripheral arteries and veins and prevents the formation of thrombosis ${ }^{20,21}$. It is also the most commonly prescribed medication for males with erectile dysfunction ${ }^{22}$.

Pentoxifylline is a non-selective phosphodiesterase inhibitor that decreases inflammation and increases the blood flow and oxygenation of tissues ${ }^{23,24}$. Pentoxifylline also decreases platelet accumulation and formation of thrombosis ${ }^{25}$. Compared with other medications in this class, pentoxifylline has fewer gastrointestinal side effects and a lower $\operatorname{cost}^{26,27}$.

Recent studies have shown that sildenafil affects growth factors such as vascular endothelial growth factor and cysteine rich-61 and thereby enhances bone healing ${ }^{14,28,29}$. Histing et al. ${ }^{19}$ reported that sildenafil enhances bone healing by increasing bone formation. Kinoshita et al. ${ }^{30}$ showed that daily injections of pentoxifylline stimulate bone formation and increase bone mass in rats. Labib and Farid ${ }^{31}$ indicated that pentoxifylline administration can be considered a reliable approach to manage osseointegration. Moreover, several studies have confirmed the positive efficacy of pentoxifylline for healing of osteoradionecrosis of the mandible ${ }^{32,33}$. Furthermore, pentoxifylline is extensively used in orthopedics to maintain viability of grafts and other vascular tissues used for regeneration treatments ${ }^{34}$.

Many studies have assessed the effects of sildenafil and pentoxifylline on wound healing; however, their efficacy for bone healing has not been well investigated. Moreover, no previous study has evaluated the efficacy of sildenafil and pentoxifylline to enhance healing of maxillofacial fractures. Considering this gap of information, our study aimed to assess the effect of sildenafil and pentoxifylline phosphodiesterase inhibitors on healing of mandibular fractures in rats.

\section{Materials and Methods}

The study protocol was approved by the Ethics Committee of Isfahan Islamic Azad University (approval No. IR.IAU. KHUISF.REC.1398.188). All rats received standard laboratory nutrition and were kept in a calm environment with controlled temperature and moisture $\left(22^{\circ} \mathrm{C} \pm 2{ }^{\circ} \mathrm{C}\right.$ and $40 \%$ -
$60 \%$ humidity) and 12:12 h light/dark cycle as instructed by Animal Welfare Information Center ${ }^{35}$. A total of 60 male $12-$ to 14-week-old Albino Wistar rats weighing 300-360 g were evaluated. They did not have any infection or pathological condition affecting the experiment. The rats were randomly divided into six groups of 10 .

Rats in group $\mathrm{C} 1$ received saline orally on a daily basis after the surgery and were sacrificed after 1 week.

Rats in group S1 received $10 \mathrm{mg} / \mathrm{kg}$ sildenafil (Sildenafil $50 \mathrm{mg}$; Marham Daru, Tehran, Iran) orally via gavage on a daily basis and were sacrificed after 1 week. The rats voluntarily consumed nutritional supplement from a syringe.

Rats in group P1 received $50 \mathrm{mg} / \mathrm{kg}$ pentoxifylline (pentoxifylline 400 mg, Extended Release; Amin Pharmaceutical, Isfahan, Iran) orally via gavage on a daily basis and were sacrificed after 1 week.

Groups C4, S4, and $\mathrm{P} 4$ received medications as in groups $\mathrm{C} 1, \mathrm{~S} 1$, and P1 but were sacrificed after 4 weeks.

The dosage of administered medications was determined according to previous similar studies ${ }^{34,36-38}$. Use of higher doses may cause greater vasodilation but may be associated with side effects such as hypotension, decreased tissue perfusion and severe anti-inflammatory responses. Use of lower doses may have no effect at all ${ }^{39}$.

\section{Surgical phase}

All rats were generally anesthetized by intramuscular injection of $5 \mathrm{mg} / \mathrm{kg}$ of ketamine (Ketamine 10\%; Alfasan, Woerden, The Netherlands) and $0.02 \mathrm{~mL} / \mathrm{kg}$ of acepromazine maleate (Neurotranq; Alfasan). Next, $0.3 \mathrm{~mL}$ of $2 \%$ lidocaine with 1:80,000 epinephrine (Persocain-E; Darou Pakhsh, Tehran, Iran) was injected at the surgical site for local anesthesia and hemostasis. The surgical site was shaved and disinfected (povidone iodine; Behvazan, Rasht, Iran). The rats were placed in the supine position and a $1 \mathrm{~cm}$ unilateral submandibular incision was made at the inferior border of the mandible under sterile conditions. After dissecting the masseter muscle, the body of the mandible was exposed. Bicortical osteotomy at the angle of the mandible was performed using a $0.5 \mathrm{~mm}$ dental fissure bur (Teeskavan, Tehran, Iran) under copious irrigation with sterile saline. The distance between bone segments was $0.5 \mathrm{~mm}$, which was equal to the bur diameter. The fracture line was fixed using a two-hole microplate (MatrixNEURO adaption plate, thickness: $0.4 \mathrm{~mm}$, pure titanium; Synthes, Oberdorf, Switzerland) and two screws of $1.5 \mathrm{~mm}$ diameter (MatrixNEURO screw, self-drilling, 
$1.5 \mathrm{~mm}$ diameter, $3 \mathrm{~mm}$ length; Synthes). Subcutaneous and cutaneous tissues were sutured using 5-0 vicryl sutures (polyglycolate coated; Supa, Tehran, Iran) and 6-0 nylon sutures (monofilament polyamide; Supa). All surgical procedures were performed by the same surgeon. All rats received $1 \mathrm{mg} /$ kg tramadol (Tramadic, 50 mg/mL; Caspian Tamin, Rasht, Iran) intramuscularly for pain control and $25 \mathrm{mg} / \mathrm{kg}$ cefazolin (Ancef, Kefzol, 1 g; Razi, Tehran, Iran) intramuscularly for infection control twice a day for 5 days. All rats received soft diet for 1 week. Fig. 1 shows the surgical steps. The rats were sacrificed by administration of $200 \mathrm{mg} / \mathrm{kg}$ sodium pentobarbital (Pental; IE Ulagay, Istanbul, Turkey) after 1 week in groups $\mathrm{C} 1, \mathrm{~S} 1$, and $\mathrm{P} 1$ and after 4 weeks in groups $\mathrm{C} 4$, $\mathrm{S} 4$, and $\mathrm{P} 4$. The respective hemimandible was then resected, and the attached soft tissue was removed. The resected hemimandibles were sent for histological analysis.

\section{Histological analysis}

Histological analysis was carried out by a pathologist who was blinded to the group allocation of samples. All specimens were fixed in $10 \%$ formalin. After fixing, the specimens were decalcified using ethylene diamine tetra-acetic acid. The specimens were then embedded in paraffin blocks and sagittally sectioned into $4 \mu \mathrm{m}$ thick slices. They were then stained with H\&E. The slides were inspected under a light microscope (Nikon Eclipse E600; Nikon, Tokyo, Japan). Each specimen was then scored based on the degree of bone healing according to the scoring system suggested by Perry et al. ${ }^{11}$ as follows:

- 1 point, only fibrous tissue

- 2 points, mainly fibrous tissue and small amount of cartilage tissue

- 3 points, equal amount of fibrous and cartilage tissue

- 4 points, completely cartilage tissue

- 5 points, mainly cartilage tissue and small amount of immature (woven) bone

- 6 points, equal amount of cartilage tissue and immature bone

- 7 points, significantly immature (woven) bone and small amount of cartilage

- 8 points, completely immature (woven) bone

- 9 points, immature bone and small amount of mature bone

- 10 points, mature (lamellar) bone

Each specimen was scored by a pathologist who was blinded to the group allocation of samples based on the degree of bone healing at the previous fracture line under a light microscope at $\times 100$ magnification.

\section{Statistical analysis}

Data were analyzed using IBM SPSS Statistics (ver. 22;
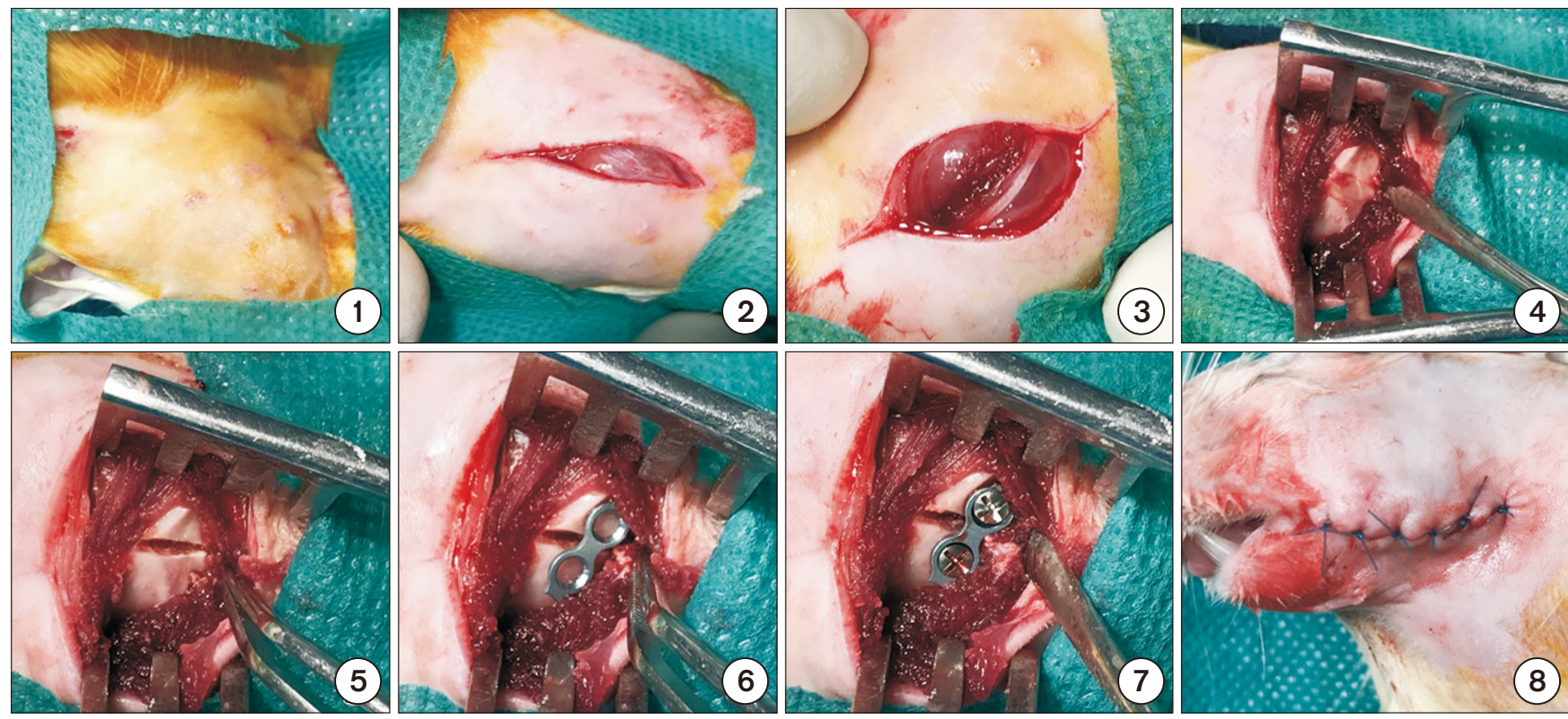

Fig. 1. Surgical steps: (1) shaving of surgical site, (2) submandibular cutaneous incision, (3) exposure of masseter muscle, (4) dissection of the masseter muscle and exposure of the body of mandible, (5) fracture line, (6) placement of microplate, (7) fixation with screw, and (8) suturing.

Mohsen MalekiGorji et al: The effect of two phosphodiesterase inhibitors on bone healing in mandibular fractures (animal study in rats). J Korean Assoc Oral Maxillofac Surg 2020 
IBM, Armonk, NY, USA) via one-way ANOVA and Tukey's post-hoc test to find significant differences between groups. The mean and standard deviation of the findings of histological analysis were reported. The level of statistical significance was set at $P<0.05$.

\section{Results}

This study evaluated the effects of two phosphodiesterase inhibitors on bone healing in mandibular fractures in rats. Sixty rats were evaluated in six groups of 10 . None of the rats expired during the study and no unwanted complications occurred. All rats tolerated the surgical procedure well. The mean rate of bone healing was 1.9, 3.9, and 4.6 in groups $\mathrm{C} 1, \mathrm{~S} 1$, and $\mathrm{P} 1$, respectively. One-way ANOVA showed that the mean rate of bone healing in mandibular fractures was significantly different among these three groups at 1 week $(P<0.001)$.(Table 1, Fig. 2) Tukey's post-hoc test revealed that the mean rate of bone healing in groups $\mathrm{S} 1$ and $\mathrm{P} 1$ was significantly higher than in group $\mathrm{C} 1$ at 1 week $(P<0.001)$. The mean rate of bone healing in group P1 was significantly higher than in group $\mathrm{S} 1$ at 1 week $(P=0.04)$.

The mean rate of bone healing was $6.7,8.5$, and 8.2 in groups $\mathrm{C} 4, \mathrm{~S} 4$, and P4, respectively. One-way ANOVA revealed that the mean rate of bone healing was significantly different among these three groups at 4 weeks $(P=0.002)$. (Table 1, Fig. 2) Tukey's test revealed that the mean rate of bone healing in groups $\mathrm{S} 4(P=0.001)$ and $\mathrm{P} 4(P=0.004)$ was significantly higher than in group $\mathrm{C} 4$ at 4 weeks but no significant difference was noted between groups P4 and S4 in this respect $(P=0.53)$. Thus, in the present study, the lowest rate of bone healing was seen in group $\mathrm{C} 1$ (control group/sacrificed after 1 week) and the highest rate of bone healing was seen in group S4 (sildenafil group/sacrificed after 4 weeks).

Fig. 3 shows histological images of study groups at $\times 100$

Table 1. Mean and standard deviation (SD) of bone healing in mandibular fractures

\begin{tabular}{cccc}
\hline Group & No. of rats & Mean \pm SD & $P$-value \\
\hline C1 & 10 & $1.9 \pm 0.7$ & \\
S1 & 10 & $3.9 \pm 0.9$ & $<0.001$ \\
P1 & 10 & $4.6 \pm 0.9$ & \\
C4 & 10 & $6.7 \pm 1.06$ & \\
S4 & 10 & $8.5 \pm 1.08$ & 0.002 \\
P4 & 10 & $8.2 \pm 1.03$ & \\
\hline
\end{tabular}

(C1: control/1 week, S1: sildenafil/1 week, P1: pentoxifylline/1 week, C4: control/4 weeks, S4: sildenafil/4 weeks, P4: pentoxifylline/4 weeks)

Mohsen MalekiGorji et al: The effect of two phosphodiesterase inhibitors on bone healing in mandibular fractures (animal study in rats). J Korean Assoc Oral Maxillofac Surg 2020 magnification.

As shown in Fig. 4, bone tissue can be divided into lamellar and woven bone according to its level of maturity. An eosinophilic area containing lacunae was noted in lamellar bone tissue under a microscope (marked by asterisks) and lines confirming periodic calcification of bone could be seen. In fact, these parts were the old host bone, which was mature and seen at both sides of the fracture line. The shorter the time duration since fracture, the less mature the tissue around the mature bone margins. The size and number of lacunae are also important. In areas marked with asterisks (old bone), the number of lacunae and their size were smaller. The area marked with a circle indicates the newly forming, immature bone. This bone has a cancellous appearance and has differences with mature bone in terms of the number of lacunae (where the osteocytes are present) and their size. The area marked with a square indicates the interface of the newly formed bone and older bone. The area marked with an arrow shows the cartilage tissue. The area marked with an $\mathrm{x}$ indicates cartilage calcification and its conversion to bone.

\section{Discussion}

This study assessed the effects of sildenafil and pentoxifylline on bone healing in mandibular fractures in rats. Healing of fractures is an important topic in maxillofacial surgery, as the patient's routine functions should be reinstated as soon as possible ${ }^{40}$. Many studies have evaluated this topic ${ }^{40,41}$ and evidence shows that the outcome of surgical procedures for treatment of fractures is influenced by a number of factors

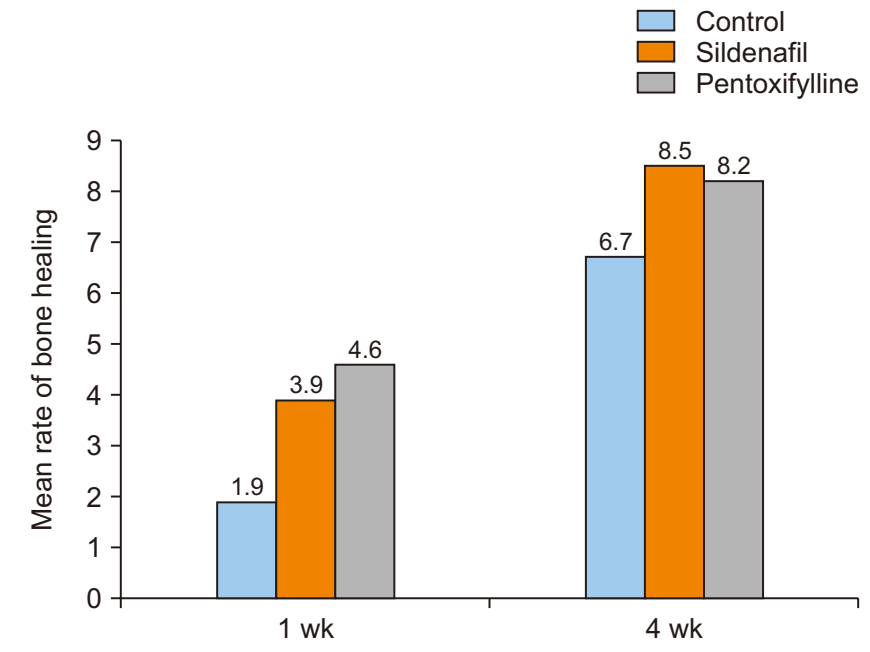

Fig. 2. Mean rate of bone healing in mandibular fractures in the study groups.

Mohsen MalekiGorji et al: The effect of two phosphodiesterase inhibitors on bone healing in mandibular fractures (animal study in rats). J Korean Assoc Oral Maxillofac Surg 2020 

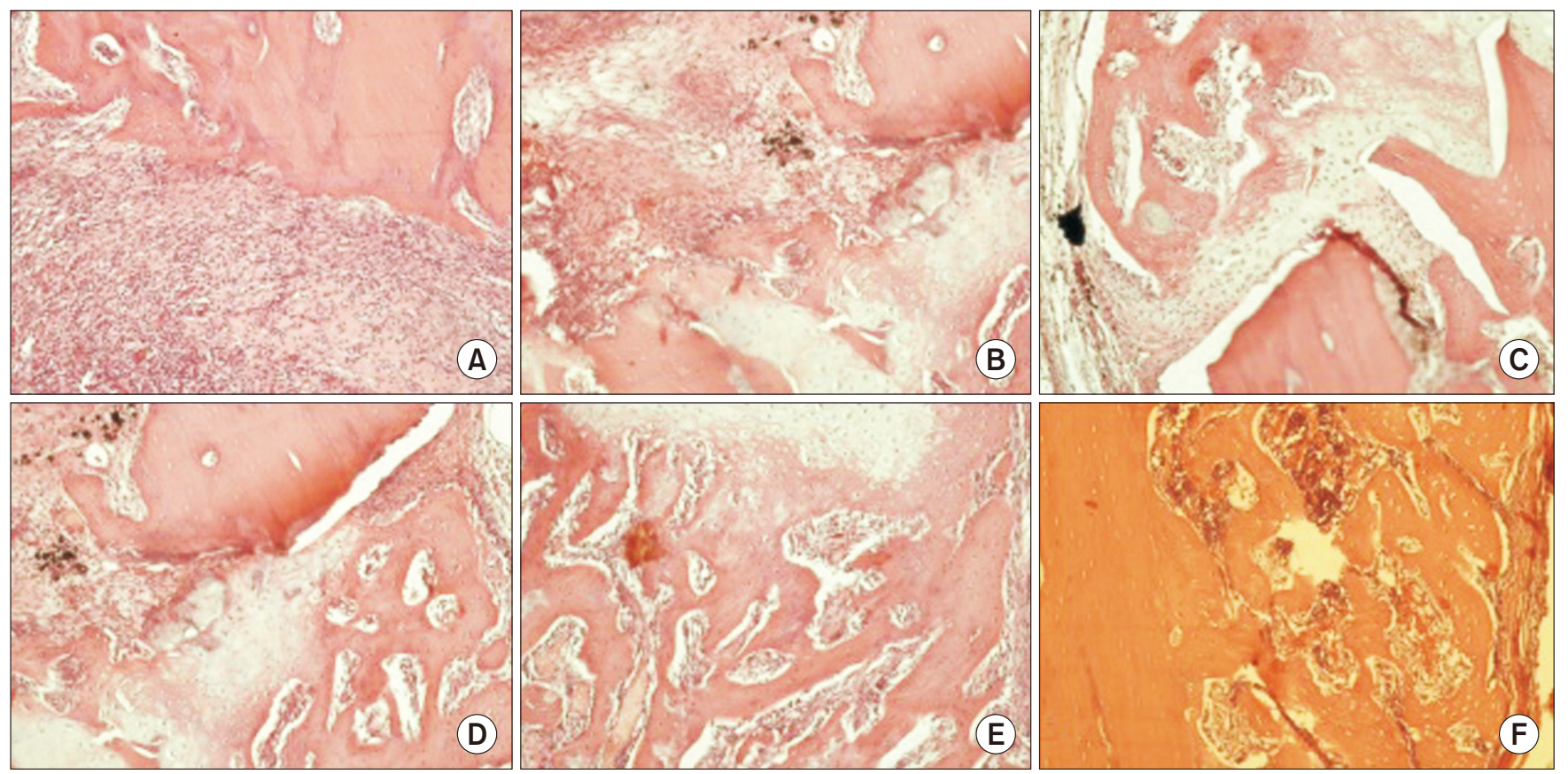

Fig. 3. Histological images of study groups (H\&E staining, $\times 100$ ). A. A specimen from group $C 1$ with bone healing score 1 (healing with fibrous tissue). B. A specimen from group S1 with bone healing score 3 (healing with equal amounts of fibrous and cartilage tissue). C. A specimen from group P1 with bone healing score 5 (healing with mainly cartilage tissue and small amount of immature [woven] bone). D. A specimen from group C4 with bone healing score 6 (healing with equal amounts of cartilage tissue and immature bone). E. A specimen from group S4 with bone healing score 7 (healing with mainly immature bone and small amount of cartilage). F. A specimen from group P4 with bone healing score 9 (healing with immature bone and small amount of mature bone).

Mohsen MalekiGorji et al: The effect of two phosphodiesterase inhibitors on bone healing in mandibular fractures (animal study in rats). J Korean Assoc Oral Maxillofac Surg 2020

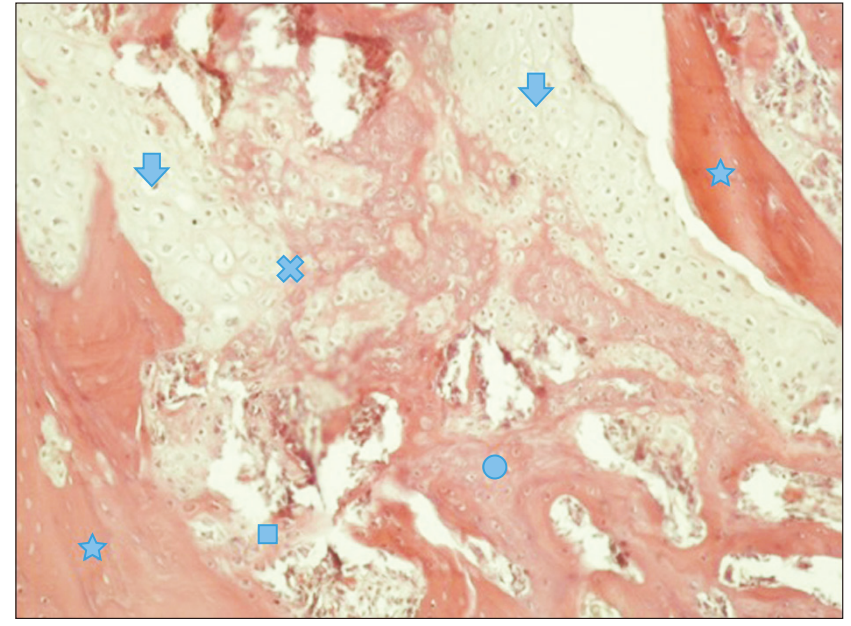

Fig. 4. Histological image of group P1 with bone healing score 5 (H\&E staining, $\times 100)$. (arrows: cartilage tissue, x: cartilage calcification and conversion to bone, asterisks: lamellar bone, circle: immature bone, square: interface of the newly formed bone and older bone)

Mohsen MalekiGorji et al: The effect of two phosphodiesterase inhibitors on bone healing in mandibular fractures (animal study in rats). J Korean Assoc Oral Maxillofac Surg 2020

such as patient-related factors, type of bone defect and type of surgical procedure ${ }^{40}$. Adequate blood supply plays a critical role in bone healing ${ }^{42,43}$, and impaired angiogenesis at the site leads to poor bone healing. Oxygen and nutrients are delivered to the site of the forming bone callus by the bloodstream. Moreover, the bloodstream delivers progenitor and inflammatory cells to the site of injury ${ }^{20,21,28}$. Nitric oxide and vasodilation are also imperative for angiogenesis ${ }^{44}$. The positive effects of nitric oxide on wound healing may be related to its functional effects on angiogenesis and inflammation. Sildenafil prevents the breakdown and degradation of nitric oxide, which leads to vasodilation and increased blood supply to the tissue ${ }^{16-18}$. Several studies have shown that sildenafil is effective for different pathological conditions via the nitric oxide pathway. Other studies have focused on the effects of sildenafil on tissue healing. Many clinical and animal studies have shown positive effects of sildenafil in cases of decreased blood supply to the skin and impaired vascularization as in ischemic wounds ${ }^{18,21,29}$. Moreover, evidence shows that enhanced bone healing by sildenafil is due to the function of cysteine-rich angiogenic inducer 61 protein, which stimulates endothelial cell migration and induces proliferation and differentiation of osteoblasts and cell adhesion ${ }^{14,45}$. Pentoxifylline is a phosphodiesterase inhibitor derived from xanthine, which has a vasodilatory effect. In contrast to most peripheral vasodilators, pentoxifylline has rheological effects on blood and decreases its viscosity ${ }^{24}$. The therapeutic effects 
of pentoxifylline are mainly attributed to its potential for increasing the blood flow and oxygenation of tissues due to its hemorheological property ${ }^{25}$. It is not clear whether pentoxifylline increases the number of osteoblasts and osteoclasts or not. Takami et al. showed that phosphodiesterase inhibitors increase the number of osteoclasts and their differentiation to osteoblasts $^{46}$. Horiuchi et al. ${ }^{47,48}$ demonstrated that pentoxifylline enhances new bone formation by upregulating the bone morphogenetic protein-2. Tsutsumimoto et al. ${ }^{49}$ indicated that pentoxifylline can be used to enhance bone formation.

A number of studies have evaluated the effects of phosphodiesterase inhibitors on bone healing with results comparable to ours. However, no previous study evaluated the effects of sildenafil and pentoxifylline on maxillofacial fractures ${ }^{42}$. The current results revealed that pentoxifylline and sildenafil have positive effects on bone healing. Our findings regarding enhanced bone healing by sildenafil are in agreement with those of Yaman et al. ${ }^{42}$ and Histing et al. ${ }^{19}$. Aydin et al. ${ }^{34}$ used pentoxifylline at a dosage similar to ours and showed that it enhanced the formation of hematoma, which is the first phase of bone healing. This result agrees with our finding. However, in contrast to our results, they showed that the anti-inflammatory effects of pentoxifylline may delay bone healing after 3 weeks $^{34}$. Our study showed positive effects of pentoxifylline on bone healing in the late stage. Since they evaluated femoral bone fractures, this discrepancy may be related to different rates and modes of metabolism of femoral bone and mandibular bone in the final stages of fracture healing.

Our results regarding enhanced bone healing by sildenafil were in line with those of Histing et al. ${ }^{19}$, with the difference that they used $5 \mathrm{mg} / \mathrm{kg}$ of sildenafil while we used $10 \mathrm{mg} /$ $\mathrm{kg}$ according to the previously published studies. The reason behind the use of $5 \mathrm{mg} / \mathrm{kg}$ dosage of sildenafil in their study was that the speed of sildenafil metabolism is higher in rats and sildenafil has a half-life of one hour in rats and four hours in humans. The $5 \mathrm{mg} / \mathrm{kg}$ dosage for rats is 5 times the standard dosage for humans ( 0.7 to $1.5 \mathrm{mg} / \mathrm{kg}$ ). Despite the different dosages used in the two studies, the outcomes were the same. Atalay et al. ${ }^{40}$ used the same dosage of pentoxifylline as ours. The mean histological score of bone healing in their study was 7.8 after 4 weeks while it was 8.2 in our study. This difference is probably due to the difference in defect size in the two studies. The bone gap created in their study after osteotomy was $1 \mathrm{~mm}$ while in our study it was $0.5 \mathrm{~mm}$. In the present study, bone healing in the pentoxifylline group was significantly higher than in sildenafil group after 1 week but the score of bone healing in the sildenafil group was higher than in the pentoxifylline group after 4 weeks. It seems that the rheological effects of pentoxifylline and reduction of blood viscosity by this medication in the first week enhanced the primary phase of healing and formation of hematoma at the site of fracture. However, the authors believe that at the end of week 4, the anti-inflammatory effects of pentoxifylline, similar to those of other non-steroidal anti-inflammatory drugs, delayed the process of bone healing. For this reason, at the end of week 4, bone healing in the sildenafil group was higher than in the pentoxifylline group. Infection also plays a role in bone healing. Aydin et al. ${ }^{34}$ showed lower bone healing at similar time points and use of equal dosage of pentoxifylline compared to our study (7.1 vs 8.2 ), which may be due to no postoperative use of antibiotics in their study. As they reported, $40 \%$ of samples in the pentoxifylline group had infection, which seemed to slow the process of bone healing. Gong et al. ${ }^{50}$ indicated that use of tadalafil and vardenafil phosphodiesterase inhibitors decreased bone mass. Their study was the only one that reported results contrary to ours. This may be attributed to different study design and different types of selective phosphodiesterase inhibitors.

Despite the abovementioned studies, our knowledge about the effects of phosphodiesterase inhibitors on bone metabolism and healing is insufficient. A good understanding of the biological events that occur in the process of bone healing is imperative to find the most efficient approach to enhance bone healing. This study was the first to show the positive effects of sildenafil and pentoxifylline on healing of mandibular bone fractures. Thus, sildenafil and pentoxifylline can be used as adjuncts to enhance bone healing.

One limitation of this study was daily use of $50 \mathrm{mg} / \mathrm{kg}$ dosage of pentoxifylline and $10 \mathrm{mg} / \mathrm{kg}$ dosage of sildenafil; thus, bone healing in response to higher and lower doses remains a matter of question. Also, due to ethical considerations, we could not enroll a larger sample size. Last but not least, it is not known to what extent the slight histological differences are clinically important. Clinical studies using different doses of sildenafil and pentoxifylline are required to assess bone healing at different time points. Also, similar studies are recommended on rabbits or dogs since they have higher histological and anatomical similarities with humans, and surgical procedures of their mandibles would be easier to perform. Moreover, radiographic and biomechanical assessments should be carried out in addition to histological analysis, and expression of genes involved in bone healing should also be evaluated. Finally, similar studies are required 
on osteoporotic mandibles and those under bisphosphonate therapy, chemotherapy and radiotherapy to assess the efficacy of these medications to enhance bone healing in pathological conditions.

\section{Conclusion}

The results of this study showed that sildenafil and pentoxifylline can be used as adjuncts to enhance bone healing in mandibular fractures in rats.

\section{ORCID}

Mohsen MalekiGorji, https://orcid.org/0000-0001-87341833

Arash Golestaneh, https://orcid.org/0000-0003-4455-7049

Seyyed Mohammad Razavi, https://orcid.org/0000-00023504-9424

\section{Author's Contributions}

M.M. participated in data collection and wrote the manuscript. A.G. and S.M.R. participated in the study design and performed the statistical analysis. All authors read and approved the final manuscript.

\section{Ethics Approval and Consent to Participate}

The study protocol was approved by the Ethics Committee of Isfahan Islamic Azad University (approval No. IR.IAU. KHUISF.REC.1398.188).

\section{Conflict of Interest}

No potential conflict of interest relevant to this article was reported.

\section{References}

1. Glória JCR, Fernandes IA, Silveira EMD, Souza GM, Rocha RL, Galvão EL, et al. Comparison of bite force with locking plates versus non-locking plates in the treatment of mandibular fractures: a meta-analysis. Int Arch Otorhinolaryngol 2018;22:181-9. https:// doi.org/10.1055/s-0037-1604056

2. Uçan MC, Koparal M, Ağaçayak S, Gunay A, Ozgoz M, Atilgan $\mathrm{S}$, et al. Influence of caffeic acid phenethyl ester on bone healing in a rat model. J Int Med Res 2013;41:1648-54. https://doi. org/10.1177/0300060513490613

3. Fernández JR, Gallas M, Burguera M, Viaño JM. A threedimensional numerical simulation of mandible fracture reduction with screwed miniplates. J Biomech 2003;36:329-37. https://doi. org/10.1016/s0021-9290(02)00416-5

4. Durmuş K, Turgut NH, Doğan M, Tuncer E, Özer H, Altuntaş EE, et al. Histopathological evaluation of the effect of locally administered strontium on healing time in mandibular fractures: an experimental study. Adv Clin Exp Med 2017;26:1063-7. https://doi. org/10.17219/acem/65477

5. Hausman MR, Schaffler MB, Majeska RJ. Prevention of fracture healing in rats by an inhibitor of angiogenesis. Bone 2001;29:5604. https://doi.org/10.1016/s8756-3282(01)00608-1

6. Dincel YM, Alagoz E, Arikan Y, Caglar AK, Dogru SC, Ortes F, et al. Biomechanical, histological, and radiological effects of different phosphodiesterase inhibitors on femoral fracture healing in rats. J Orthop Surg (Hong Kong) 2018;26:2309499018777885. https:// doi.org/10.1177/2309499018777885

7. Hankenson KD, Zimmerman G, Marcucio R. Biological perspectives of delayed fracture healing. Injury 2014;45 Suppl 2:S8-15. https://doi.org/10.1016/j.injury.2014.04.003

8. Cook JJ, Summers NJ, Cook EA. Healing in the new millennium: bone stimulators: an overview of where we've been and where we may be heading. Clin Podiatr Med Surg 2015;32:45-59. https://doi. org/10.1016/j.cpm.2014.09.003

9. Chao EY, Inoue N. Biophysical stimulation of bone fracture repair, regeneration and remodelling. Eur Cell Mater 2003;6:72-84; discussion 84-5. https://doi.org/10.22203/ecm.v006a07

10. Massari L, Caruso G, Sollazzo V, Setti S. Pulsed electromagnetic fields and low intensity pulsed ultrasound in bone tissue. Clin Cases Miner Bone Metab 2009;6:149-54.

11. Perry AC, Prpa B, Rouse MS, Piper KE, Hanssen AD, Steckelberg $\mathrm{JM}$, et al. Levofloxacin and trovafloxacin inhibition of experimental fracture-healing. Clin Orthop Relat Res 2003;(414):95-100. https://doi.org/10.1097/01.blo.0000087322.60612.14

12. Zandi M, Dehghan A, Amini P, Rezaeian L, Doulati S. Evaluation of mandibular fracture healing in rats under zoledronate therapy: a histologic study. Injury 2017;48:2683-7. https://doi.org/10.1016/ j.injury.2017.10.026

13. Colnot $\mathrm{C}, \mathrm{Lu} \mathrm{C}, \mathrm{Hu} \mathrm{D}, \mathrm{Helms} \mathrm{JA}$. Distinguishing the contributions of the perichondrium, cartilage, and vascular endothelium to skeletal development. Dev Biol 2004;269:55-69. https://doi. org/10.1016/j.ydbio.2004.01.011

14. Lienau J, Schell H, Epari DR, Schütze N, Jakob F, Duda GN, et al. CYR61 (CCN1) protein expression during fracture healing in an ovine tibial model and its relation to the mechanical fixation stability. J Orthop Res 2006;24:254-62. https://doi.org/10.1002/jor.20035

15. Keramaris NC, Calori GM, Nikolaou VS, Schemitsch EH, Giannoudis PV. Fracture vascularity and bone healing: a systematic review of the role of VEGF. Injury 2008;39 Suppl 2:S45-57. https:// doi.org/10.1016/S0020-1383(08)70015-9

16. Diwan AD, Wang MX, Jang D, Zhu W, Murrell GA. Nitric oxide modulates fracture healing. J Bone Miner Res 2000;15:342-51. https://doi.org/10.1359/jbmr.2000.15.2.342

17. Baldik Y, Talu U, Altinel L, Bilge H, Demiryont M, Aykac-Toker G. Bone healing regulated by nitric oxide: an experimental study in rats. Clin Orthop Relat Res 2002;(404):343-52. https://doi. org/10.1097/00003086-200211000-00051

18. Derici H, Kamer E, Unalp HR, Diniz G, Bozdag AD, Tansug T, et al. Effect of sildenafil on wound healing: an experimental study. Langenbecks Arch Surg 2010;395:713-8. https://doi.org/10.1007/ s00423-009-0471-2

19. Histing T, Marciniak K, Scheuer C, Garcia P, Holstein JH, Klein M, et al. Sildenafil accelerates fracture healing in mice. J Orthop Res 2011;29:867-73. https://doi.org/10.1002/jor.21324

20. Vidavalur R, Penumathsa SV, Zhan L, Thirunavukkarasu M, Maulik N. Sildenafil induces angiogenic response in human coronary arteriolar endothelial cells through the expression of thioredoxin, hemeoxygenase and vascular endothelial growth factor. Vascul Pharmacol 2006;45:91-5. https://doi.org/10.1016/j.vph.2006.03.010 
21. Hart K, Baur D, Hodam J, Lesoon-Wood L, Parham M, Keith K, et al. Short- and long-term effects of sildenafil on skin flap survival in rats. Laryngoscope 2006;116:522-8. https://doi.org/10.1097/01. mlg.0000200792.67802.3b

22. Das A, Xi L, Kukreja RC. Phosphodiesterase-5 inhibitor sildenafil preconditions adult cardiac myocytes against necrosis and apoptosis. Essential role of nitric oxide signaling. J Biol Chem 2005;280:12944-55. https://doi.org/10.1074/jbc.M404706200

23. Essayan DM. Cyclic nucleotide phosphodiesterases. J Allergy Clin Immunol 2001;108:671-80. https://doi.org/10.1067/ mai.2001.119555

24. Delanian S, Porcher R, Rudant J, Lefaix JL. Kinetics of response to long-term treatment combining pentoxifylline and tocopherol in patients with superficial radiation-induced fibrosis. J Clin Oncol 2005;23:8570-9. https://doi.org/10.1200/JCO.2005.02.4729

25. Ward A, Clissold SP. Pentoxifylline. A review of its pharmacodynamic and pharmacokinetic properties, and its therapeutic efficacy. Drugs 1987;34:50-97. https://doi.org/10.2165/00003495198734010-00003

26. Bayat M, Amini A, Rezaie F, Bayat S. Patents of pentoxifylline administration on some diseases and chronic wounds. Recent Pat Regen Med 2014;4:137-43. https://doi.org/10.2174/221029650466 6140813194744

27. Vashghani Farahani MM, Masteri Farahani R, Mostafavinia A, Abbasian MR, Pouriran R, Noruzian M, et al. Effect of pentoxifylline administration on an experimental rat model of femur fracture healing with intramedullary fixation. Iran Red Crescent Med J 2015;17:e29513. https://doi.org/10.5812/ircmj.29513

28. Ghofrani HA, Osterloh IH, Grimminger F. Sildenafil: from angina to erectile dysfunction to pulmonary hypertension and beyond. Nat Rev Drug Discov 2006;5:689-702. https://doi.org/10.1038/nrd2030

29. Koneru S, Varma Penumathsa S, Thirunavukkarasu M, Vidavalur R, Zhan L, Singal PK, et al. Sildenafil-mediated neovascularization and protection against myocardial ischaemia reperfusion injury in rats: role of VEGF/angiopoietin-1. J Cell Mol Med 2008;12:265164. https://doi.org/10.1111/j.1582-4934.2008.00319.x

30. Kinoshita T, Kobayashi S, Ebara S, Yoshimura Y, Horiuchi H, Tsutsumimoto T, et al. Phosphodiesterase inhibitors, pentoxifylline and rolipram, increase bone mass mainly by promoting bone formation in normal mice. Bone 2000;27:811-7. https://doi.org/10.1016/ s8756-3282(00)00395-1

31. Labib GS, Farid RM. Osteogenic effect of locally applied Pentoxyfilline gel: in vitro and in vivo evaluations. Drug Deliv 2015;22:1094-102. https://doi.org/10.3109/10717544.2014.884193

32. Kahenasa N, Sung EC, Nabili V, Kelly J, Garrett N, Nishimura I. Resolution of pain and complete healing of mandibular osteoradionecrosis using pentoxifylline and tocopherol: a case report. Oral Surg Oral Med Oral Pathol Oral Radiol 2012;113:e18-23. https:// doi.org/10.1016/j.oooo.2011.10.014

33. Delanian S, Depondt J, Lefaix JL. Major healing of refractory mandible osteoradionecrosis after treatment combining pentoxifylline and tocopherol: a phase II trial. Head Neck 2005;27:114-23. https:// doi.org/10.1002/hed.20121

34. Aydin K, Sahin V, Gürsu S, Mercan AS, Demir B, Yildirim T. Effect of pentoxifylline on fracture healing: an experimental study. Eklem Hastalik Cerrahisi 2011;22:160-5.

35. Clark JD, Gebhart GF, Gonder JC, Keeling ME, Kohn DF. The 1996 guide for the care and use of laboratory animals. ILAR J 1997;38:41-8. https://doi.org/10.1093/ilar.38.1.41

36. Schlundt C, El Khassawna T, Serra A, Dienelt A, Wendler S, Schell $\mathrm{H}$, et al. Macrophages in bone fracture healing: their essential role in endochondral ossification. Bone 2018;106:78-89. https://doi. org/10.1016/j.bone.2015.10.019

37. Rotter N, Haisch A, Bücheler M. Cartilage and bone tissue engineering for reconstructive head and neck surgery. Eur Arch Otorhinolaryngol 2005;262:539-45. https://doi.org/10.1007/s00405-004-0866-1

38. Vega LG. Reoperative mandibular trauma: management of posttrau- matic mandibular deformities. Oral Maxillofac Surg Clin North Am 2011;23:47-61, v-vi. https://doi.org/10.1016/j.coms.2010.12.003

39. Irkorucu O, Taşcilar O, Cakmak GK, Karakaya K, Emre AU, Ucan $\mathrm{BH}$, et al. The effect of sildenafil on an animal model for ischemic colitis. Dig Dis Sci 2008;53:1618-23. https://doi.org/10.1007/ s10620-007-0033-9

40. Atalay Y, Bozkurt MF, Gonul Y, Cakmak O, Agacayak KS, Köse I, et al. The effects of amlodipine and platelet rich plasma on bone healing in rats. Drug Des Devel Ther 2015;9:1973-81. https://doi. org/10.2147/DDDT.S80778

41. Anitua E, Sánchez M, Orive G, Andía I. The potential impact of the preparation rich in growth factors (PRGF) in different medical fields. Biomaterials 2007;28:4551-60. https://doi.org/10.1016/ j.biomaterials.2007.06.037

42. Yaman F, Atilgan S, Günes N, Agacayak S, Günay A, Ucan MC, et al. Phosphodiesterase-5 inhibitors may facilitate bone defect recovery. Eur Rev Med Pharmacol Sci 2011;15:1301-5.

43. Rajkumar DS, Faitelson AV, Gudyrev OS, Dubrovin GM, Pokrovski MV, Ivanov AV. Comparative evaluation of enalapril and losartan in pharmacological correction of experimental osteoporosis and fractures of its background. J Osteoporos 2013;2013:325693. https://doi.org/10.1155/2013/325693

44. Corbett SA, Hukkanen M, Batten J, McCarthy ID, Polak JM, Hughes SP. Nitric oxide in fracture repair. Differential localisation, expression and activity of nitric oxide synthases. J Bone Joint Surg Br 1999;81:531-7. https://doi.org/10.1302/0301-620x.81b3.8852

45. Si W, Kang Q, Luu HH, Park JK, Luo Q, Song WX, et al. CCN1/ Cyr61 is regulated by the canonical Wnt signal and plays an important role in Wnt3A-induced osteoblast differentiation of mesenchymal stem cells. Mol Cell Biol 2006;26:2955-64. https://doi. org/10.1128/MCB.26.8.2955-2964.2006

46. Takami M, Cho ES, Lee SY, Kamijo R, Yim M. Phosphodiesterase inhibitors stimulate osteoclast formation via TRANCE/ RANKL expression in osteoblasts: possible involvement of ERK and p38 MAPK pathways. FEBS Lett 2005;579:832-8. https://doi. org/10.1016/j.febslet.2004.12.066

47. Horiuchi H, Saito N, Kinoshita T, Wakabayashi S, Tsutsumimoto $\mathrm{T}$, Otsuru S, et al. Enhancement of recombinant human bone morphogenetic protein-2 (rhBMP-2)-induced new bone formation by concurrent treatment with parathyroid hormone and a phosphodiesterase inhibitor, pentoxifylline. J Bone Miner Metab 2004;22:32934. https://doi.org/10.1007/s00774-003-0490-y

48. Horiuchi H, Saito N, Kinoshita T, Wakabayashi S, Tsutsumimoto T, Takaoka K. Enhancement of bone morphogenetic protein-2-induced new bone formation in mice by the phosphodiesterase inhibitor pentoxifylline. Bone 2001;28:290-4. https://doi.org/10.1016/s87563282(00)00450-6

49. Tsutsumimoto T, Wakabayashi S, Kinoshita T, Horiuchi H, Takaoka $\mathrm{K}$. A phosphodiesterase inhibitor, pentoxifylline, enhances the bone morphogenetic protein-4 (BMP-4)-dependent differentiation of osteoprogenitor cells. Bone 2002;31:396-401. https://doi.org/10.1016/ s8756-3282(02)00839-6

50. Gong Y, Xu CY, Wang JR, Hu XH, Hong D, Ji X, et al. Inhibition of phosphodiesterase 5 reduces bone mass by suppression of canonical Wnt signaling. Cell Death Dis 2014;5:e1544. https://doi. org/10.1038/cddis.2014.510

How to cite this article: MalekiGorji M, Golestaneh A, Razavi SM. The effect of two phosphodiesterase inhibitors on bone healing in mandibular fractures (animal study in rats). J Korean Assoc Oral Maxillofac Surg 2020;46:258-265. https://doi.org/10.5125/ jkaoms.2020.46.4.258 